\title{
Do increases in the availability of standing dead trees affect the abundance, nest-site use, and niche partitioning of great spotted and middle spotted woodpeckers in riverine forests?
}

\author{
Ziemowit Kosiński ${ }^{1}$ (D) Monika Pluta ${ }^{2}$ - Anna Ulanowska ${ }^{3}$. \\ Lukasz Walczak $^{1} \cdot$ Aleksander Winiecki $^{1} \cdot$ Mateusz Zarębski $^{4}$
}

Received: 16 November 2016/Revised: 31 May 2017/ Accepted: 18 August 2017/ Published online: 28 August 2017

(C) The Author(s) 2017. This article is an open access publication

\begin{abstract}
Standing dead trees may be a limited resource for woodpeckers in managed forests, especially for species that rely on dead wood for their nest or roost cavity, and as foraging sites. Effective conservation strategies for woodpeckers require a detailed knowledge of species' responses to dead wood availability. To investigate the importance of standing dead wood (snags) for the abundance and nest-site use of the great spotted woodpecker Dendrocopos major and middle spotted woodpecker Leiopicus medius in mature riverine forests, we compared the responses of birds between two periods-before mass mortality, and during a pulse in standing dead trees. The density of standing dead trees available for cavity excavation by the great spotted woodpecker and the middle spotted woodpecker increased significantly during the study period: 37-fold and 4-fold, respectively. Temporal trends in the abundance of both woodpecker species from 2000 to 2015 were not significant. Great spotted woodpeckers were significantly more likely to use dead trees and places with wounds in species other than oak and ash during the outbreak period than in the pre-outbreak period. Middle spotted woodpeckers were significantly less likely to excavate cavities in tree species other than oak and ash in the outbreak period, but dead trees were more likely selected. An interspecific comparison suggests that the probability of a nest-hole having been excavated by a middle spotted woodpecker increased with a nest-hole sited in ash, in a dead tree, in a limb/branch, and decreased with
\end{abstract}

Communicated by Khoon Meng Wong.

This article belongs to the Topical Collection: Forest and plantation biodiversity.

Ziemowit Kosiński

zkosinsk@amu.edu.pl

1 Department of Avian Biology and Ecology, Institute of Environmental Biology, Faculty of Biology, Adam Mickiewicz University in Poznań, Umultowska 89, 61-614 Poznań, Poland

2 Potarzyca, Wyzwolenia 61, 63-200 Jarocin, Poland

3 Os. Przemysława 22/25, 61-064 Poznań, Poland

4 Prądzyńskiego 21/2, 61-532 Poznań, Poland 
a nest-hole in a closed forest. These findings suggest that woodpecker species, especially weak excavators, may benefit from an increase in dead wood availability leading to nest niche shifts into more favorable substrates for cavity excavation. However, a strong increase in dead wood availability does not modify the general pattern of niche partitioning between great spotted and middle spotted woodpeckers. Conservation plans for the specialized middle spotted woodpecker must consider the preference for dead and decaying trees. The decreasing number of large ashes and oaks, and the lack of natural regeneration of the latter species, may negatively affect the middle spotted woodpecker in the future.

Keywords Pulse of dead wood $\cdot$ Nest-site use $\cdot$ Niche partitioning $\cdot$ Great spotted woodpecker Dendrocopos major . Middle spotted woodpecker

Leiopicus medius · Riverine forest · Ash dieback

\section{Introduction}

Dying and standing dead trees (snags) have been recognized as a crucial resource for primary cavity excavators, particularly woodpeckers, providing foraging, and roost and nest sites (Short 1979; Winkler and Christie 2002). The relationship between dead-wood supply and the abundance of some woodpecker species has been well documented through studies demonstrating low woodpecker abundance when snags occur in very low densities, or are experimentally removed or created (Zarnowitz and Manuwal 1985; McPeek et al. 1987; Hutto and Gallo 2006; Kilgo and Vukovich 2014). However, other studies have found no such relationship across a range of measured snag densities, snag sizes, and snag conditions (e.g. Sedgewick and Knopf 1986; Gunn and Hagan 2000; Spiering and Knight 2005; Smith 2007).

The presence of standing dead wood may be especially beneficial for species with weaker excavating abilities, i.e. 'snag specialists' (Hågvar et al. 1990; Smith 2007; Lõhmus et al. 2010). However, past and present human activities, e.g. deforestation, impoverishment of tree species diversity, short-rotation schemes, active fire suppression, and removal of dead wood, have led to a decline in the numbers of dead and decaying trees in forest ecosystems (Angelstam and Mikusiński 1994; Mikusiński and Angelstam 1997; Mikusiński 2006). Some of the specialist, dead-wood dependent woodpecker species have declined dramatically in their geographic ranges (e.g. Bütler et al. 2004; Czeszczewik and Walankiewicz 2006; Mikusiński 2006; Roberge et al. 2008). Since the availability of snags suitable for cavity excavation in managed forests is low as a direct result of forestry practice, snags are often considered a limiting resource for woodpeckers (Newton 1994).

The great spotted woodpecker Dendrocopos major and the middle spotted woodpecker Leiopicus medius coexist in old, European deciduous forests (Winkler and Christie 2002; Kosiński 2006). Both species are primary excavators. The middle spotted woodpecker feeds predominantly on bark- and foliage-living arthropods by gleaning and probing their prey. The great spotted woodpecker exploits food resources at deeper levels of wood by excavating and probing on trees. During the nestling period, both species feed heavily on defoliating caterpillars. The beginning of the breeding season in both species is highly synchronized and does not vary between the species (Michalek and Miettinen 2003; Pasinelli 2003; Kosiński and Ksit 2006).

The mechanisms that allow for the coexistence of ecologically similar species include habitat partitioning, use of resources during different times, and/or differential use of food resources (Gause 1934; Schoener 1974). Earlier studies show that separation of the nesting 
niches of great spotted and middle spotted woodpeckers in riverine forests is expressed by the preference for different tree species, tree condition, and nest placement in relation to the forest edge (Kosiński and Winiecki 2004). Middle spotted woodpeckers show an affinity to nest near forest edges and favor nesting in snags, but great spotted woodpeckers more frequently nest in closed forests, and prefer nesting in live oaks Quercus sp. and alders Alnus glutinosa. However, other studies suggest that the type of forest stand, proportion of different tree species, age of tree stand, and share of dead trees may modify intra- and interspecific nest-site characteristics and niche partitioning of both woodpecker species (Wesołowski and Tomiałojć 1986; Kosiński et al. 2006; Pasinelli 2007; Domokos and Cristea 2014). To our knowledge, only one long-term study has examined the population response of three woodpecker species to increased snag density in Europe (Smith 2007). Furthermore, the ecological consequences of mass mortality of trees, such as those resulting from insect and disease outbreaks, for woodpecker nest-site selection in the forests of continental Europe are unknown.

In this study, we investigated the abundance and nest-site use of the great spotted and middle spotted woodpeckers in riverine forests in Central Europe as a response to a pulse in snag availability. This increased snag density, mainly oaks Quercus robur and ashes Fraxinus excelsior, was driven primarily by drought-mediated tree mortality (Schwartz 2008; Kamiński et al. 2011; Miler 2016). For oaks, mortality of stressed trees was affected by lethal attacks from oak tree borers, i.e. Agrilus biguttatus, in 2005 and 2006 (Wargo 1996; Thomas et al. 2002; Schwartz 2008). In an area of the oldest stands (59 ha), the density of dead oaks with a diameter at breast height (Dbh) $\geq 14 \mathrm{~cm}$ increased by $38 \%$, from 5.4 snags $1 \mathrm{ha}^{-1}$ in 2006 to 7.5 snags $1 \mathrm{ha}^{-1}$ in 2007 , and remained stable in the years 2009-2012 (Jarocin Forest District, unpubl. data). The causal agent of ash dieback is fungal disease caused by the ascomycete Hymenoscyphus fraxineus (Pautasso et al. 2013; Kowalski et al. 2016). Large-scale ash dieback, which first appeared in Poland in the 1990s (Przybył 2002), spread rapidly. The density of dead ashes (Dbh $\geq 14 \mathrm{~cm}$ ) increased by $45 \%$, from 1.6 snags $1 \mathrm{ha}^{-1}$ in 2006 to 2.3 snags $1 \mathrm{ha}^{-1}$ in 2007 . However, in 2009 the density of dead ashes reached 9.8 snags $1 \mathrm{ha}^{-1}$, and then decreased to 6.1 snags $1 \mathrm{ha}^{-1}$ in 2012. Tree dieback was observed in variable intensity across the study area, probably as an effect of varying tree density and species composition, as well as the position of stands above the groundwater table.

Great spotted and middle spotted woodpeckers differ in their adaptations for drilling and drumming, i.e. the middle spotted woodpecker's neck muscles are less suitable for excavation and drumming. These differences have been well documented not only through knowledge of species skeletomuscular systems (Jenni 1981), but also through studies demonstrating that both species differ in terms of nest-site characteristics; the latter species clearly prefers dead trees or excavates its cavities only in soft or decayed parts of living trees (Kosiński and Winiecki 2004; Kosiński et al. 2006; Pasinelli 2007). Although the role of dead or decaying wood as a resource for cavity excavation is well-documented, its impact on the abundance of the middle spotted woodpecker is controversial. Hertel (2003) suggests that lowland beech forests with a lot of standing dead wood can be colonized by middle spotted woodpeckers, even when the density of large oaks is low. Weggler et al. (2013) assume that increased amounts of standing dead wood are one of the possible explanations for the striking population growth of the middle spotted woodpecker in Zurich canton. However, other studies suggest that snags can be used for nesting if available, but their presence is not a necessary condition for great spotted and middle spotted woodpeckers' occurrence and abundance (Lovaty 2002; Kosiński and Kempa 2007; Smith 2007; Stachura-Skierczyńska and Kosiński 2016; but see Spühler et al. 2014). 
As the middle spotted woodpecker seems to be largely confined to dead wood, we hypothesized that a pulse in snag availability should positively affect their abundance. Moreover, we expected that dead trees should be used with higher frequency rates in the outbreak than in pre-outbreak period.

The great spotted and middle spotted woodpeckers are the two most common woodpecker species in old-growth deciduous forests in Central Europe (Kosiński and Kempa 2007; Domokos and Cristea 2014; Wesołowski et al. 2015). As major creators of cavities, both species provide a critical resource for secondary cavity users (Mazgajski 2003; Smith 2005; Wesołowski 2007; Lučan et al. 2009). Moreover, the middle spotted woodpecker is listed in Annex I of the European Union Birds Directive, and is the subject of special conservation measures concerning their habitat to ensure their survival and reproduction in their area of distribution. Thus, identifying the role of habitat elements that are potentially critical requirements for woodpeckers species, e.g. dead wood, is an important step in developing promising conservation strategies, and this is essential information for policy planning bodies and decision-makers (Zawadzka et al. 2013).

In this article, we examine whether: (1) the abundance of the great spotted and middle spotted woodpeckers is associated with dead tree availability; (2) increases in dead wood availability affect intraspecific variation in nest-site use; and (3) changes in dead wood availability modify niche partitioning between two ecologically related species.

\section{Materials and methods}

\section{Study area}

We established a study site in the riverine forest of the Warta river valley, western Poland, near Czeszewo $\left(17^{\circ} 31^{\prime} \mathrm{E}, 52^{\circ} 09^{\prime} \mathrm{N}\right), 50 \mathrm{~km}$ south east of Poznań. This woodland is a remnant of flood-plain forests, which in the past covered narrow alluvial strips along major European rivers. In some parts of Europe, this forest has completely disappeared. Currently, the total area of riverine forests in Poland is estimated at $27 \mathrm{~km}^{2}$ (Matuszkiewicz, 2001). Field work was carried out on a 222.6 ha plot, which encompasses 186 ha of forest. The vegetation consists of Quercus-Fraxinus-Ulmus (Fraxino-Ulmetum) woodland in the flooded parts and Quercus-Carpinus (Stellario-carpinetum) forest on the higher ground. The rest of the study area (39 ha, 17\%) is formed by oxbow lakes and extensively used meadows. The study forest differs in terms of age, species composition and spatial structures because of previous human impact. The oldest, near-natural stands are distinguished from younger and human-altered stands with regards to the height of trees (up to $33 \mathrm{~m}$ in ashes, and $32 \mathrm{~m}$ in oaks), the multi-story profile of stands (4-5 layers), and the high diversity of tree species (up to 7 species). In 2000, about $40 \%$ of tree stands on the study plot (74 ha) were ca. 155-165 years old, 24\% (43 ha)-81-120 years old, 28\% (51 ha) $-41-80$ years old and 4\% (10 ha) $-\leq 40$ years old; ca. 4\% (8 ha) was covered by coniferous stands. By 2013, the proportion of the oldest forest stands ( $>120$ years old) had increased to $62 \%$, and the maximum age of stands reached 184 years. Since 1959, the oldest near-natural stands have been protected within two reserves ("Czeszewo" and "Lutynia"), and have been almost unmanaged. In 2004, the whole study area was declared a nature reserve: "Czeszewski Las". Our study area is a part of both the NATURA 2000 Special Protection Area Middle Warta River Valley PLB300002, with the middle spotted woodpecker as one of the target species, and the Ostoja Nadwarciańska Special Area of 
Conservation PLH300009. Further characteristics of the forest stands and their management can be found elsewhere (Kosiński et al. 2006; Kamiński et al. 2011).

\section{Woodpecker occurrence data}

We counted middle spotted woodpeckers from 2000 to 2015 and great spotted woodpeckers in 2000-2009 and 2013-2015. However, to examine the potential effect of dead wood availability on nest-site characteristics we used data collected in 2000-2005 for middle spotted and in 2001-2005 for great spotted woodpeckers, and in 2013-2015 for both species. To estimate the number and distribution of middle spotted woodpecker territories, the study plot was surveyed in each of the pre-breeding seasons (from the second half of March till the end of April), when aggressive interactions among individuals are most common (Pasinelli et al. 2001). We performed four to five complete censuses during 2000-2005, and two to three censuses in other years. Censuses were conducted with a minimum interval of 1 week. All counts were based on the same call-playback method, which has been recommended for middle spotted woodpecker censuses as a way of overcoming difficulties in detection and mapping (Kosiński and Winiecki 2003; Kosiński et al. 2004; Stachura-Skierczyńska and Kosiński 2016). The survey was conducted by listening for and recording vocal responses of pairs/individuals at selected points. The number of playback locations amounted to 58 during a single census. To provoke responses from territorial birds, we used taped calls (rattle- and advertising-calls of males). To reduce the probability of some individuals being attracted away from their territories by the playback technique, we applied the following parameters: a minimum distance of 150-200 m between points, a maximum time of $40 \mathrm{~s}$ for the stimulation in one bout, and a minimum interval of 1-2 min for listening. After the first bird's response, the taped calls were stopped to determine the initial location of the bird. We recorded and mapped the woodpecker's initial position, behavior, type of call, direction of movements, and sex, if possible. We paid special attention to register simultaneously active birds to separate neighboring pairs/territories. To locate the positions of birds precisely, we walked along forest roads, division lines, and shore lines of oxbow lakes. Therefore, points of stimulation were distributed unevenly. The observations began in the morning at 7-8 AM and continued until late afternoon. Our experience suggests that time of day does not affect the detection of middle spotted woodpeckers in the pre-breeding season. Analysis of the data enabled an estimation of the number of birds holding territory on the study plot. We use the term "territory", because middle spotted woodpeckers defend almost exclusive territories during March and April, with both sexes participating to similar degrees in territorial defense (Pasinelli et al. 2001). On the basis of our long-term experience, we assumed that two registrations in the pre-breeding period was sufficient to accept a territory (Lõhmus et al. 2016; Stachura-Skierczyńska and Kosiński 2016), and to exclude transient/floater birds (Pasinelli et al. 2001; Robles and Ciudad 2012). Moreover, two visits allow an experienced observer to find almost $100 \%$ of territories in the pre-breeding period ( $\mathrm{Z}$. Kosiński unpubl. data). All middle spotted woodpecker territories were checked to find a nest-hole, except for the years 2010-2012. A search for nest-holes began in the prebreeding period (2000-2005 and 2008-2010); however, in other years we focused our field procedure mainly on the detection of calling nestlings. We conducted extensive nest searches by systematically walking each territory in the second part of May and at the beginning of June. In total, in both periods we found nest-holes in 60 and $77 \%$ territories, respectively. These values are most likely close to the number of breeding attempts that survive to fledgling period (Kosiński and Ksit 2006). However, the lower value in the first 
period may be affected by the lower level of experience of observers in nest-searching. The distribution of cavities reflected the territory distribution (Kosiński and Winiecki 2003).

No playback censuses were conducted for great spotted woodpeckers, because of its inappropriateness for this species owing to its high density in riverine forests and difficulties in separation of neighboring pairs (Tomiałojć 1980). In 2001-2005, the nest-holes of great spotted woodpeckers were found at the beginning of the breeding season either by the sound of excavation or signs of wood-boring, as well as by detection of adults and calling nestlings during the latter period. In 2013-2015, we detected nest-holes by listening for begging calls of the young. Since in this period nest-holes were sought on a smaller forest area of 154 ha, data from the pre-outbreak period were limited to the same area. We aborted attempts to check part of the study area due to the high number of fallen logs and leaning trees, which rendered the field work time-consuming and risky. Moreover, this area was rarely used as a nesting habitat by the middle spotted woodpecker. Based on the high survival rates of great spotted woodpecker nests (e.g. Mazgajski 2002; Kosiński and Ksit 2006), and the high efficiency of nest searching methods, we assumed that probably all the nesting attempts were recorded in each year. Almost every year we found a few pairs with newly fledged offspring, with poor flying ability outside the nest-holes. To assess the total number of breeding pairs, these families were added to the number of active cavities. Adults with fledglings that flew well were not included in the total number of pairs. Such a treatment reduces the risk of an erroneous population estimate.

\section{Description of nest-sites and changes in dead tree numbers}

In this analysis, we used nine parameters for nest-sites: tree species, tree condition (live vs. dead), part of tree (trunk vs. limb/branch), condition of tree fragment (live vs. dead), diameter at breast height, nest height above the ground, presence or absence of wounds/ cracks at nest- site, presence or absence of fruiting bodies of polypores within $1 \mathrm{~m}$ of the cavity entrance, and location of nesting tree in relation to distance from the forest edge (forest edge $\leq 25 \mathrm{~m}$ vs. closed forest $>25 \mathrm{~m}$ from an edge).

To describe the changes in the availability of standing dead trees in pre-outbreak and outbreak periods, we used data obtained from randomly selected circular plots with a radius of $10 \mathrm{~m}$ ( $0.033 \mathrm{ha})$ established in 46 territories of great spotted woodpeckers in 2001-2002 and 91 territories of middle spotted woodpeckers in 2000-2004, as well as in 137 and 72 territories of both species in 2013-2015, respectively. The maximum distance between nesting trees and selected points for each woodpecker species was defined as the radius of a circle with an area equal to the male core area in the pre-breeding season, i.e. 7.3 ha for the middle spotted woodpecker (Pasinelli et al. 2001), and 3.0 ha for the great spotted woodpecker (Bachmann and Pasinelli 2002). The detailed procedure for randomization was described thoroughly by Kosiński and Winiecki (2004). In each plot, we measured all trees with a diameter at breast height (DBH) sufficiently large for hole excavation, i.e. $\geq 14 \mathrm{~cm}$ for middle spotted woodpeckers and $\geq 19 \mathrm{~cm}$ for great spotted woodpeckers (Kosiński and Ksit 2007). In total, in the 'pre-outbreak' and 'outbreak' periods we measured 395 and 1066 available trees in the great spotted woodpecker territories, as well as 951 and 670 trees in the middle spotted woodpecker territories, respectively. 


\section{Statistical analysis}

We used generalized linear models (GLMs), with binomial error distribution, and logit link function to test for differences in nest-sites of the great spotted and middle spotted woodpeckers before the outbreak and during the pulse in dead wood supply, with period ('pre-outbreak' and 'outbreak') as a response variable, and characteristics of nest-sites as the explanatory variables. Interspecific differences in the nest-sites of the two woodpecker species were compared using species as the categorical dependent variable (Pasinelli 2007; Vierling et al. 2009). To test the effect of pre-outbreak and outbreak conditions on nest-site use, we included all the original variables of interest and their interactions with the study period.

We used generalized linear mixed effects models (GLMMs) to test the effect of tree condition ('alive' and 'dead') as a fixed effect on the utilization of trees ('available' and 'used') as a response variable. Separate models were run for the great spotted and middle spotted woodpeckers. We treated the study period ('pre-outbreak' and 'outbreak') as a random effect. This approach was used to control for the overall increase in available dead trees when comparing selection between pre-outbreak and outbreak periods. To test the significance of the random effect, we performed the likelihood ratio test comparing the log likelihood functions of the full model and the model without the random effect.

Results of multiple regression analyses may be affected by strong correlations among the explanatory variables (Dormann et al. 2013). Therefore, the correlation structure of ordinal and continuous variables was investigated (separately for each woodpecker species) before GLM analysis. Spearman rank correlations indicated one pair of moderately/ strongly correlated explanatory variables $(p<0.05)$, these being tree condition with the condition of the tree fragment (great spotted woodpecker- $\left|r_{S}\right|=0.62$; middle spotted woodpecker $\left.-\left|r_{S}\right|=0.59\right)$. Since in fact the condition of the tree fragment is largely affected by tree condition, we analyzed reduced models by including only one member of the most related variables along with all the other explanatory variables. We developed a set of 5 candidate models (Table 1). Candidate models consisted of: the intercept-only model (model 1); two models including tree characteristics with only one member of the two most related variables, i.e. tree condition and condition of tree fragment (models 2-3); a model with a combination of nest-tree characteristics (except for condition of the tree fragment) and distance to forest edge (model 4); and the full model with all explanatory variables (model 5).

Table 1 Candidate model set for the analysis of changes in nest-site selection of great spotted and middle spotted woodpecker in response to dead wood supply

\begin{tabular}{ll}
\hline Model & Model function \\
\hline 1 & Intercept-only model \\
2 & Tree species + Dbh + tree condition + cavity height + part of tree + wounds + conks of fungi \\
3 & Tree species + Dbh + condition of tree fragment + cavity height + part of \\
& tree + wounds + conks of fungi \\
4 & Tree species + Dbh + tree condition + cavity height + part of tree + wounds + conks of \\
& fungi + distance to forest edge \\
5 & Tree species + Dbh + tree condition + condition of tree fragment + cavity height + part of \\
& tree + wounds + conks of fungi + distance to forest edge
\end{tabular}


Following the information-theoretic approach (Burnham and Anderson 2002), multimodel inference and model averaging were used to test for differences between the nest sites of the two woodpecker species in pre-outbreak and outbreak periods of dead wood supply, and to test for interspecific differences in nest sites. The relative support for each model was assessed using Akaike's Information Criterion corrected for small sample size (AICc) (Burnham and Anderson 2002). The subset of models with substantial support (delta AICc $<2$ compared to the best model) was selected, with their parameter estimates and standard errors averaged (Burnham and Anderson 2002; Bartoń 2009). For all models, Akaike weights were calculated to provide a measure of the probability that a given model was the most strongly supported in the model set, with higher weights indicating better explanatory power. We calculated odds ratios and their $95 \%$ confidence intervals (CI) to characterize the effect of explanatory variables (nest-site characteristics) on binary responses (the two study periods or woodpecker species) for model parameters based on model-averaging (Rita and Komonen 2008). In subsequent analyses, we used only complete records for nest-sites. All analyses were carried out in 'MuMin' (Bartoń 2009), and 'Ime4' (Bates et al. 2014) packages using R v.3.3.2 (R Development Core Team 2016).

\section{Results}

\section{Changes in woodpecker abundance}

The number of great spotted woodpecker pairs varied between 22 in 2001 (1.4 pairs $10 \mathrm{ha}^{-1}$ of forest area) and 51 in 2015 (3.3 pairs $10 \mathrm{ha}^{-1}$ ). The number of middle spotted woodpecker pairs varied between 29 in 2003 and 2009 (1.6 pairs $10 \mathrm{ha}^{-1}$ of forest area), and 38 in 2000 (2.0 pairs $10 \mathrm{ha}^{-1}$ ) (Fig. 1). A simple linear regression analysis suggests that temporal trends in the abundance of both woodpeckers from 2000 to 2015 were not significant (great spotted woodpecker: slope $\pm \mathrm{SE}=1.009 \pm 0.484, \mathrm{t}=2.09$, df $=11$, $p=0.061 ;$ middle spotted woodpecker: slope $\pm \mathrm{SE}=-0.057 \pm 0.136, \mathrm{t}=-0.42$, $\mathrm{df}=14, p=0.680$ ). Quadratic analysis of woodpecker abundance across time did not improve results (both trends were not significant).

\section{Changes in standing dead tree availability in pre-outbreak and outbreak periods}

The percentage of plots with standing dead trees available for cavity excavation increased from $2.2 \%(\mathrm{~N}=46)$ in the pre-outbreak period to $54.0 \%(\mathrm{~N}=137)$ in the outbreak period for the great spotted woodpecker, and from $17.6 \%(\mathrm{~N}=91)$ to $55.6 \%(\mathrm{~N}=72)$ for the middle spotted woodpecker, respectively. The density of dead trees increased significantly between the pre-outbreak and outbreak periods for both the great spotted woodpecker (Mann-Whitney test, $\mathrm{Z}=6.03, p<0.0001)$, and middle spotted woodpecker $(\mathrm{Z}=5.09$, $p<0.0001)$. Mean snag density available for the great spotted woodpecker increased by 37 -fold, and for middle spotted woodpecker by 4-fold (Fig. 2). In the pre-outbreak period, we found only one dead ash sufficiently large for cavity excavation by the great spotted woodpecker; however, in the outbreak period oaks comprised $56.9 \%$, ashes-25.7\%, and other tree species-17.4\% of standing dead trees $(\mathrm{N}=109)$. For the middle spotted woodpecker, oaks in the pre-outbreak period represented $33.3 \%$, ashes-37.5\%, and other tree species-29.2\% of standing dead trees available for cavity excavation $(\mathrm{N}=24)$. In 


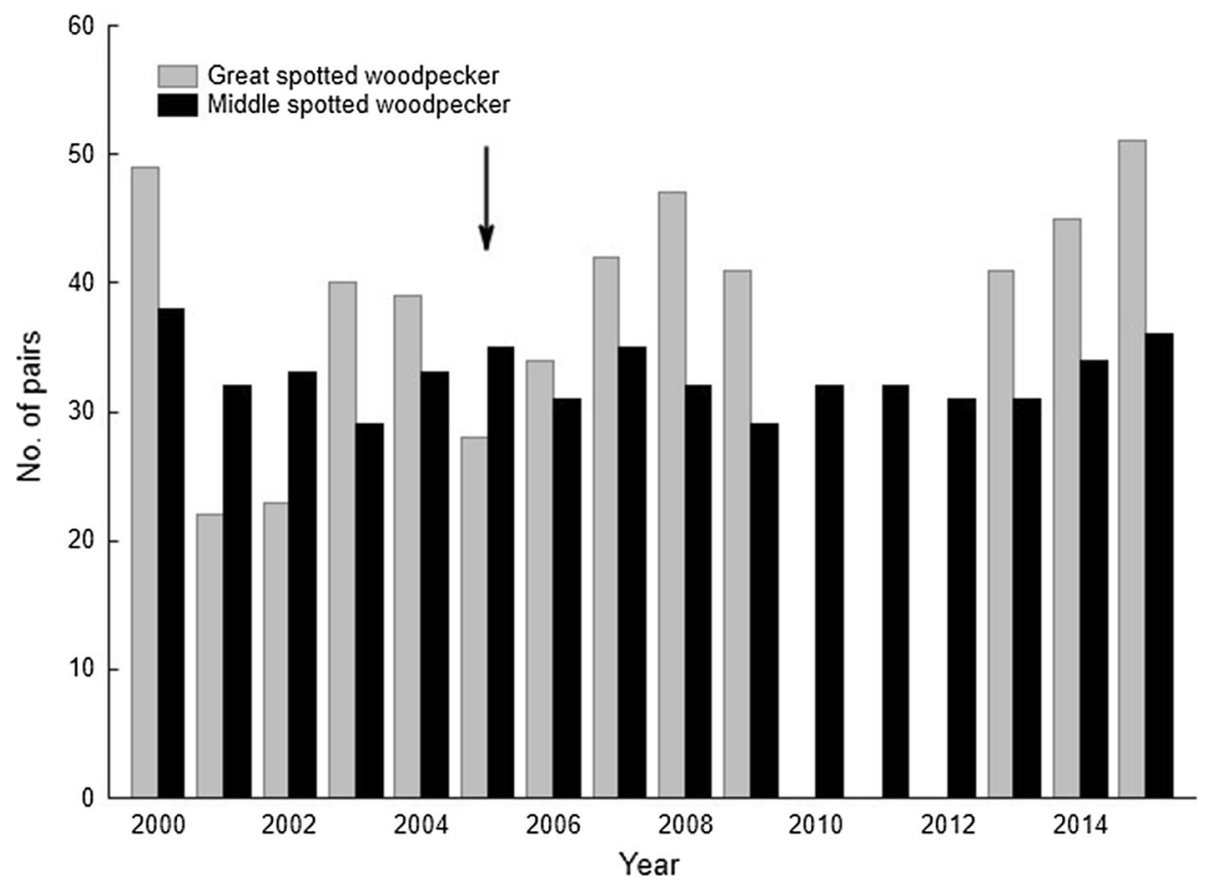

Fig. 1 Changes in abundance of great spotted and middle spotted woodpeckers in Nature Reserve "Czeszewski Las" in 2000-2015. In 2010-2012, the abundance of the great spotted woodpecker was not assessed. Arrow indicates the start of lethal attacks from oak tree borers and divide study period into two parts-before and after a mass mortality of trees

the outbreak period, these species represented 35.5, 40.8, and $23.7 \%(\mathrm{~N}=76)$ of trees, respectively. The breast height diameter (Dbh) of standing dead trees in pre-outbreak and outbreak periods was $38.2 \mathrm{~cm}(\mathrm{~N}=1)$ and $42.0 \pm 18.6 \mathrm{~cm}$ (range 19-108; $\mathrm{N}=109$ ) for great spotted woodpeckers. The mean Dbh of dead trees potentially available for middle spotted woodpeckers in successive periods was $30.9 \pm 11.2 \mathrm{~cm}($ range $14-54 ; \mathrm{N}=24)$ and $36.9 \pm 21.3 \mathrm{~cm}$ (range 14-95; $\mathrm{N}=76$ ), respectively.

GLMMs show that the tree condition affected the utilization of trees by the middle spotted woodpecker irrespective of the study period (Table 2). It was found that the study period ('pre-outbreak' and 'outbreak'), when treated as a random effect, was inert (likelihood ratio tests, $p>0.05$ ). Dead trees were used for nesting significantly more frequently according to their availability.

\section{Characteristics of nest-sites}

Univariate comparisons showed that some nest site characteristics differed significantly between the pre-outbreak and dead tree outbreak, for both great spotted and middle spotted woodpeckers (Table 3). Both woodpecker species used dead trees twice as often in outbreak as in pre-outbreak periods. Cavities made by great spotted woodpeckers were found in wounds more frequently in the outbreak period. Middle spotted woodpeckers nested significantly more frequently in closed forests in the dead tree outbreak. Other nest-site characteristics did not differ between the pre-outbreak and outbreak of dead trees. 


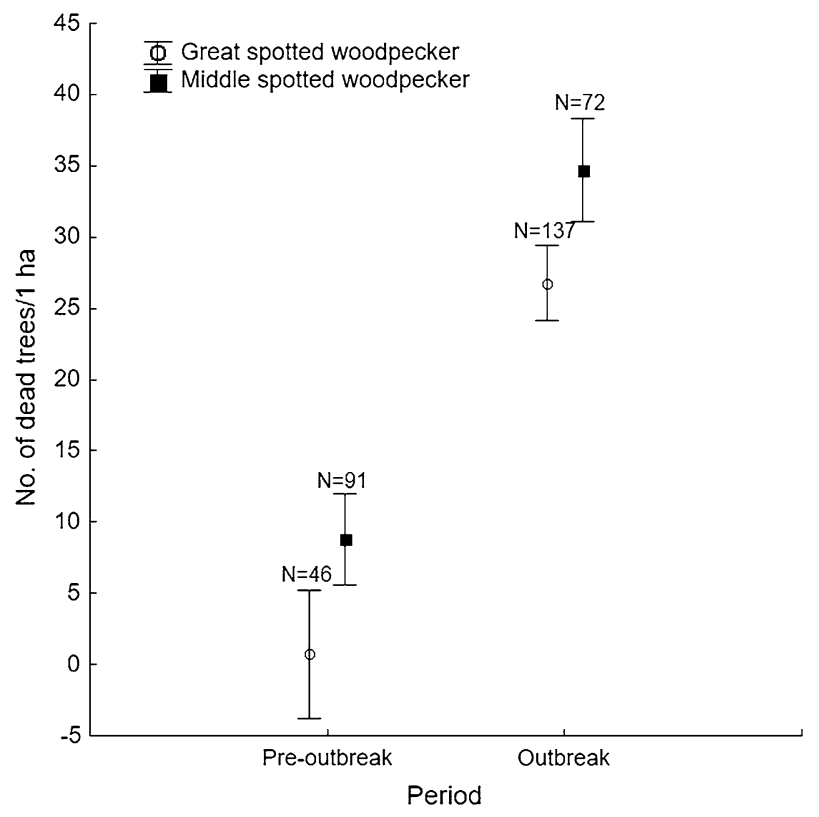

Fig. 2 Mean density of snags $( \pm \mathrm{SE})$ sufficiently large for hole excavation for great spotted and middle spotted woodpeckers before and after the mass mortality of trees in Nature Reserve "Czeszewski Las"

Table 2 Model coefficients from generalized linear mixed models explaining the utilization of dead trees according to their availability for great spotted and middle spotted woodpeckers

\begin{tabular}{|c|c|c|c|c|c|}
\hline Species & Fixed effect & Estimate & SE & $2.5 \% \mathrm{CL}$ & $97.5 \% \mathrm{CL}$ \\
\hline \multirow[t]{2}{*}{ D. major $^{\mathrm{a}}$} & Intercept & 0.108 & 0.008 & 0.089 & 0.127 \\
\hline & Tree condition-dead & 0.032 & 0.029 & -0.024 & 0.089 \\
\hline \multirow[t]{2}{*}{ L. medius ${ }^{\mathrm{a}}$} & Intercept & 0.077 & 0.007 & 0.051 & 0.100 \\
\hline & Tree condition-dead & 0.224 & 0.025 & 0.174 & 0.274 \\
\hline
\end{tabular}

a Study period ('pre-outbreak' and 'outbreak') was entered as a random effect; likelihood ratio tests, $p>0.05$ in both cases

\section{Intraspecific variation in nest-site use}

For the great spotted woodpecker, the three best models (models 5, 2, and 4; delta AICc $<2$ compared to the best model) accounted for most of the Akaike model weight (approximately 0.88 ), indicating they were better supported by the data than the remaining models (Table 4). The first-ranked model, with an Akaike weight of 0.413, was 2.2 times more likely than the third-ranked model, with an Akaike weight of 0.186. The parameters based on model-averaging show that three variables had effect sizes larger than their standard errors (SE), and their 95\% confidence intervals (CI) of estimates did not contain the value 0 (Table 5). This suggests tree species other than oak and ash, dead trees, and places with wounds were more important for differentiating between the nest sites of the great spotted woodpecker in both study periods. The odds ratios indicated that in the outbreak period other tree species, dead trees, and tree fragments with wounds were selected 2.89, 4.27, and 
Table 3 Characteristics of cavity placement of great spotted and middle spotted woodpeckers before the outbreak and during the pulse in dead wood supply

\begin{tabular}{|c|c|c|c|c|c|c|}
\hline \multirow[t]{2}{*}{ Variable } & \multicolumn{2}{|c|}{ Great spotted woodpecker } & \multirow[t]{2}{*}{ Test value $(p)$} & \multicolumn{2}{|c|}{$\begin{array}{l}\text { Middle spotted } \\
\text { woodpecker }\end{array}$} & \multirow[t]{2}{*}{ Test value $(p)$} \\
\hline & $\begin{array}{l}\text { Pre- } \\
\text { outbreak } \\
(\mathrm{N}=146)\end{array}$ & $\begin{array}{l}\text { Outbreak } \\
(\mathrm{N}=134)\end{array}$ & & $\begin{array}{l}\text { Pre- } \\
\text { outbreak } \\
(\mathrm{N}=114)\end{array}$ & $\begin{array}{l}\text { Outbreak } \\
(\mathrm{N}=75)\end{array}$ & \\
\hline Dbh $(\mathrm{cm})$ & $59.1 \pm 19.0$ & $61.1 \pm 21.5$ & $\begin{array}{c}\mathrm{t}=-0.800 \\
(p=0.424)\end{array}$ & $61.7 \pm 28.9$ & $64.0 \pm 27.2$ & $\begin{array}{l}\mathrm{t}=-0.546 \\
(p=0.586)\end{array}$ \\
\hline $\begin{array}{l}\text { Cavity height } \\
\text { (m) }\end{array}$ & $10.1 \pm 6.2$ & $9.7 \pm 5.3$ & $\begin{array}{l}\mathrm{t}=0.536 \\
\quad(p=0.592)\end{array}$ & $11.3 \pm 7.0$ & $12.2 \pm 7.2$ & $\begin{array}{l}\mathrm{t}=-0.864 \\
\quad(p=0.389)\end{array}$ \\
\hline \multicolumn{7}{|l|}{ Tree species (\%) } \\
\hline $\begin{array}{l}\text { Oak Quercus } \\
\text { robur }\end{array}$ & 77.4 & 74.6 & $\chi^{2}=3.65$ & 50.9 & 57.3 & $\chi^{2}=4.58$ \\
\hline $\begin{array}{l}\text { Ash Fraxinus } \\
\text { excelsior }\end{array}$ & 13.7 & 9.7 & $(p=0.161)$ & 29.8 & 34.7 & $(p=0.101)$ \\
\hline Other & 8.9 & 15.7 & & 19.3 & 8.0 & \\
\hline \multicolumn{7}{|c|}{ Tree condition (\%) } \\
\hline Live & 94.5 & 87.3 & $\chi^{2}=4.46$ & 81.6 & 60.0 & $\chi^{2}=10.70$ \\
\hline Dead & 5.5 & 12.7 & $(p=0.035)$ & 18.4 & 40.0 & $(p=0.001)$ \\
\hline \multicolumn{7}{|l|}{ Part of tree $(\%)$} \\
\hline Trunk & 81.5 & 85.1 & $\chi^{2}=0.64$ & 61.4 & 65.3 & $\chi^{2}=0.30$ \\
\hline Limb/branch & 18.5 & 14.9 & $(p=0.425)$ & 38.6 & 34.7 & $(p=0.584)$ \\
\hline \multicolumn{7}{|c|}{ Condition of tree fragment $(\%)$} \\
\hline Live & 80.1 & 79.1 & $\chi^{2}=0.46$ & 51.8 & 44.0 & $\chi^{2}=1.09$ \\
\hline Dead & 19.9 & 20.9 & $(p=0.830)$ & 48.2 & 56.0 & $(p=0.297)$ \\
\hline \multicolumn{7}{|l|}{ Wounds (\%) } \\
\hline Absent & 17.8 & 8.2 & $\chi^{2}=5.61$ & 9.6 & 5.3 & $\chi^{2}=1.15$ \\
\hline Present & 82.2 & 91.2 & $(p=0.018)$ & 90.4 & 94.7 & $(p=0.283)$ \\
\hline \multicolumn{7}{|c|}{ Conks of fungi (\%) } \\
\hline Absent & 54.1 & 53.0 & $\chi^{2}=0.04$ & 46.5 & 49.3 & $\chi^{2}=0.15$ \\
\hline Present & 45.9 & 47.0 & $(p=0.851)$ & 53.5 & 50.7 & $(p=0.702)$ \\
\hline \multicolumn{7}{|c|}{ Distance to forest edge (\%) } \\
\hline Forest edge & 55.5 & 51.5 & $\chi^{2}=0.45$ & 77.2 & 64.0 & $\chi^{2}=3.90$ \\
\hline Closed forest & 44.5 & 48.5 & $(p=0.504)$ & 22.8 & 36.0 & $(p=0.048)$ \\
\hline
\end{tabular}

Nest holes from all years are pooled

2.71 times more often relative to the reference categories (oak, living trees, places without wounds respectively) than in the pre-outbreak period (Table 5).

For the middle spotted woodpecker, the three best models (models 4, 2, and 5; delta AICc $<2$ compared to the best model) accounted for most of the Akaike model weight (approximately 0.95) (Table 4). The first-ranked model, with an Akaike weight of 0.418, was 2.31 times more likely than the third-ranked model, with an Akaike weight of 0.181 . The parameters based on model-averaging suggest tree species other than oak and ash, and dead trees were more important for differentiating between the nest sites of the middle spotted woodpecker in both study periods. The odds ratio of a nest-site being excavated in other tree species in the outbreak period was 4.17 times less than in the pre-outbreak 
Table 4 Model-selection statistic for the analysis of the changes in nest-site selection of great spotted and middle spotted woodpeckers in response to dead wood supply

\begin{tabular}{|c|c|c|c|c|c|c|}
\hline Species & Model & Model function & $\mathrm{df}^{\mathrm{a}}$ & $\mathrm{AICc}^{\mathrm{b}}$ & $\Delta \mathrm{AICc}^{\mathrm{c}}$ & Weight $^{\mathrm{d}}$ \\
\hline \multirow[t]{5}{*}{ D. major } & 5 & $\begin{array}{l}\text { Tree species }+ \text { Dbh }+ \text { tree } \\
\text { condition }+ \text { condition of tree } \\
\text { fragment }+ \text { cavity height }+ \text { part of } \\
\text { tree }+ \text { wounds }+ \text { conks of fungi }+ \text { distance } \\
\text { to forest edge }\end{array}$ & 11 & 385.6 & 0.00 & 0.413 \\
\hline & 2 & $\begin{array}{l}\text { Tree species }+ \text { Dbh }+ \text { tree condition }+ \text { cavity } \\
\text { height }+ \text { part of tree }+ \text { wounds }+ \text { conks of } \\
\text { fungi }\end{array}$ & 9 & 386.3 & 0.78 & 0.280 \\
\hline & 4 & $\begin{array}{l}\text { Tree species }+ \text { Dbh }+ \text { tree condition }+ \text { cavity } \\
\text { height }+ \text { part of tree }+ \text { wounds }+ \text { conks of } \\
\text { fungi }+ \text { distance to forest edge }\end{array}$ & 10 & 387.1 & 1.59 & 0.186 \\
\hline & 1 & Intercept-only model & 1 & 388.4 & 2.81 & 0.101 \\
\hline & 3 & $\begin{array}{l}\text { Tree species }+ \text { Dbh }+ \text { condition of tree } \\
\text { fragment }+ \text { cavity height }+ \text { part of } \\
\text { tree }+ \text { wounds }+ \text { conks of fungi }\end{array}$ & 9 & 391.7 & 6.13 & 0.019 \\
\hline \multirow[t]{5}{*}{ L. medius } & 4 & $\begin{array}{l}\text { Tree species }+ \text { Dbh }+ \text { tree condition }+ \text { cavity } \\
\text { height }+ \text { part of tree }+ \text { wounds }+ \text { conks of } \\
\text { fungi }+ \text { distance to forest edge }\end{array}$ & 10 & 250.5 & 0.00 & 0.418 \\
\hline & 2 & $\begin{array}{l}\text { Tree species }+ \text { Dbh }+ \text { tree condition }+ \text { cavity } \\
\text { height }+ \text { part of tree }+ \text { wounds }+ \text { conks of } \\
\text { fungi }\end{array}$ & 9 & 250.9 & 0.34 & 0.352 \\
\hline & 5 & $\begin{array}{l}\text { Tree species }+ \text { Dbh }+ \text { tree } \\
\text { condition }+ \text { condition of tree } \\
\text { fragment }+ \text { cavity height }+ \text { part of } \\
\text { tree }+ \text { wounds }+ \text { conks of fungi }+ \text { distance } \\
\text { to forest edge }\end{array}$ & 3 & 252.2 & 1.67 & 0.181 \\
\hline & 1 & Intercept-only model & 1 & 254.9 & 4.39 & 0.046 \\
\hline & 3 & $\begin{array}{l}\text { Tree species }+ \text { Dbh }+ \text { condition of tree } \\
\text { fragment }+ \text { cavity height }+ \text { part of } \\
\text { tree }+ \text { wounds }+ \text { conks of fungi }\end{array}$ & 9 & 260.4 & 9.93 & 0.003 \\
\hline
\end{tabular}

The best models (separated by $\triangle \mathrm{AICc}<2$ ) are highlighted in bold

${ }^{\text {a }}$ Degrees of freedom

b Akaike's information criterion

c Difference in AICc relative to the model with the lowest AICc

d Models are ranked according to their Akaike weight; higher weights indicate more parsimonious models

period. In the outbreak period, dead trees were selected 3.78 times often than living trees than was the case in the pre-outbreak period (Table 5).

\section{Interspecific variation in nest-site use}

Of the five models examined, only one (model 4) was well supported by the data, as indicated by both delta AICc value and model weight (Table 6). The model parameters suggest that the probability of a nest-hole having been excavated by the middle spotted woodpecker increased with the nest-hole being in ash, in a dead tree, in a limb/branch, and decreased with a nest-hole being in a closed forest (Table 7). The odds ratios indicated that 
Table 5 Model coefficients and odds ratios of the environmental variables included in the best ranked models explaining changes in nest-site selection of great spotted and middle spotted woodpeckers in response to dead wood supply

\begin{tabular}{|c|c|c|c|c|c|c|c|}
\hline Species & Variable & Estimate & SE & $\begin{array}{l}2.5 \% \\
\mathrm{CL}\end{array}$ & $\begin{array}{l}97.5 \% \\
\text { CL }\end{array}$ & $\begin{array}{l}\text { Odds } \\
\text { ratio }\end{array}$ & $\begin{array}{l}\text { Odds ratio } \\
\text { CI }\end{array}$ \\
\hline \multirow[t]{10}{*}{ D. major $^{\mathrm{a}}$} & Tree species-other & 1.062 & 0.440 & 0.195 & 1.928 & 2.89 & $1.22-6.88$ \\
\hline & Tree species-ash & -0.279 & 0.441 & -1.147 & 0.590 & 0.76 & $0.32-1.80$ \\
\hline & Dbh & 0.011 & 0.007 & -0.003 & 0.025 & 1.01 & $1.00-1.02$ \\
\hline & Tree condition-dead & 1.452 & 0.697 & 0.081 & 2.822 & 4.27 & $1.08-16.81$ \\
\hline & $\begin{array}{l}\text { Condition of tree fragment- } \\
\text { live }\end{array}$ & 0.437 & 0.573 & -0.032 & 1.894 & 2.54 & $0.97-6.65$ \\
\hline & Cavity height & -0.013 & 0.027 & -0.067 & 0.041 & 0.99 & $0.94-1.04$ \\
\hline & Part of tree-limb/branch & -0.020 & 0.474 & -0.953 & 0.913 & 0.98 & $0.39-2.49$ \\
\hline & Wounds_-present & 0.997 & 0.421 & 0.169 & 0.824 & 2.71 & $1.18-6.20$ \\
\hline & Conks of fungi-present & 0.101 & 0.255 & -0.401 & 0.602 & 1.11 & $0.67-1.83$ \\
\hline & $\begin{array}{l}\text { Distance to forest edge- } \\
\text { closed forest }\end{array}$ & 0.180 & 0.247 & -0.246 & 0.773 & 1.30 & $0.78-2.17$ \\
\hline \multirow[t]{10}{*}{ L. medius ${ }^{\mathrm{a}}$} & Tree species-other & -1.430 & 0.586 & -2.587 & -0.274 & 0.24 & $0.08-0.76$ \\
\hline & Tree species-ash & -0.208 & 0.447 & -1.091 & 0.675 & 0.81 & $0.34-1.96$ \\
\hline & Dbh & -0.001 & 0.007 & -0.015 & 0.014 & 1.00 & $0.99-1.01$ \\
\hline & Tree condition-dead & 1.330 & 0.424 & 0.494 & 2.166 & 3.78 & $1.64-8.73$ \\
\hline & Cavity height & 0.022 & 0.033 & -0.042 & 0.086 & 1.02 & $0.96-1.09$ \\
\hline & Part of tree-limb/branch & -0.256 & 0.464 & -1.172 & 0.660 & 0.77 & $0.31-1.93$ \\
\hline & Wounds-present & 0.526 & 0.640 & -0.738 & 1.789 & 1.69 & $0.48-5.98$ \\
\hline & Conks of fungi-present & -0.200 & 0.331 & -0.853 & 0.452 & 0.82 & $0.43-1.57$ \\
\hline & $\begin{array}{l}\text { Distance to forest edge- } \\
\text { closed forest }\end{array}$ & 0.356 & 0.392 & -0.133 & 1.265 & 1.76 & $0.88-3.54$ \\
\hline & $\begin{array}{l}\text { Condition of tree fragment- } \\
\text { live }\end{array}$ & 0.078 & 0.283 & -0.648 & 1.464 & 1.50 & $0.52-4.32$ \\
\hline
\end{tabular}

${ }^{a}$ Estimation based on model-averaging. See Table 4 for the full list of models tested

for the middle spotted woodpecker ashes, dead trees, and limbs/branches were selected $2.63,3.25$, and 2.73 times more likely relative to the reference categories (oak, living tree, $\mathrm{limb} /$ branch respectively) than was the case for the great spotted woodpecker. Moreover, the odds ratio for a nest site being in a forest edge was 2.17 times less for the great spotted woodpecker than the odds of the event occurring for the middle spotted woodpecker (Table 7). The interaction terms including characteristics of nest-sites and study periods were not significant.

\section{Discussion}

Our results suggest that in mature riverine forests woodpecker abundance does not appear to be limited by the presence of snags. We did not find any evidence that the great spotted and middle spotted woodpeckers tended to increase in abundance over the 16-year period. The density of standing dead trees found in our study area varied greatly between the preoutbreak and outbreak periods, from a value typical for managed forests to a value close to 
Table 6 Model-selection statistic for the analysis of niche differentiation between great spotted and middle spotted woodpeckers in response to dead wood supply

\begin{tabular}{|c|c|c|c|c|c|}
\hline Model & Model function & $\mathrm{df}^{\mathrm{a}}$ & $\mathrm{AICc}^{\mathrm{b}}$ & $\Delta \mathrm{AICc} c^{\mathrm{c}}$ & Weight $^{\mathrm{d}}$ \\
\hline 4 & $\begin{array}{l}\text { Tree species }+ \text { Dbh }+ \text { tree condition }+ \text { cavity } \\
\text { height }+ \text { part of tree }+ \text { wounds }+ \text { conks of } \\
\text { fungi }+ \text { distance to forest edge }\end{array}$ & 20 & 582.9 & 0.00 & 0.802 \\
\hline 5 & $\begin{array}{l}\text { Tree species }+ \text { Dbh }+ \text { tree condition }+ \text { condition of tree } \\
\text { fragment }+ \text { cavity height }+ \text { part of tree }+ \text { wounds }+ \text { conks } \\
\text { of fungi }+ \text { distance to forest edge }\end{array}$ & 22 & 585.9 & 2.98 & 0.181 \\
\hline 2 & $\begin{array}{l}\text { Tree species }+ \text { Dbh }+ \text { tree condition }+ \text { cavity height }+ \text { part } \\
\text { of tree }+ \text { wounds }+ \text { conks of fungi }\end{array}$ & 18 & 591.0 & 8.05 & 0.014 \\
\hline 3 & $\begin{array}{l}\text { Tree species }+ \text { Dbh }+ \text { condition of tree fragment }+ \text { cavity } \\
\text { height }+ \text { part of tree }+ \text { wounds }+ \text { conks of fungi }\end{array}$ & 18 & 594.6 & 11.66 & 0.002 \\
\hline 1 & Intercept-only model & 1 & 634.4 & 51.50 & 0.000 \\
\hline
\end{tabular}

For each variable interaction with Study period was included in the model. The best model (separated by $\triangle \mathrm{AICc}<2$ ) is highlighted in bold

${ }^{\text {a }}$ Degrees of freedom

b Akaike's information criterion

${ }^{c}$ Difference in AICc relative to the model with the lowest AICc

${ }^{\mathrm{d}}$ Models are ranked according to their Akaike weight; higher weights indicate more parsimonious models

that reported from primeval lowland forests of temperate Europe, respectively (Walankiewicz et al. 2002). These results are in line with previous studies which examined the role of snags for the great spotted and middle spotted woodpeckers. In two mature oak woodlands in England the great spotted woodpecker showed strong selection for nesting in dead snags (Smith 2007). However, the availability of dead snags did not seem to affect population increase, i.e. the number of breeding pairs increased (Smith 2005), whereas the number of cavities in dead snags remained constant and no trend was discernible over time (Smith 2007). It was found that standing dead trees in the studied forests varied between 6 and 12 and 2 and 6 dead stems ha ${ }^{-1}$, respectively, with a trend for increasing over a 20 -year period (Smith 2007). However, the density of the great spotted woodpecker (individuals $\mathrm{km}^{-1}$ ) in coniferous stands in Białowieża Forest was dependent on the basal area of dead trees, it being the highest in primeval stands where the basal area of dead snags was 20 times larger than that in the nature reserves and managed stands (Czeszczewik et al. 2013). This suggests that retention of dead trees in coniferous forests may substantially increase habitat quality, i.e. this may be a driver of patch-occupancy dynamics and species density (van Horne 1983; Johnson 2007; Robles and Ciudad 2012), which is generally unsuitable even for a generalist woodpecker species, because of the low number of native deciduous trees suitable for excavation (Barrientos 2010). It has been suggested that with increasing numbers, the great spotted woodpecker is able to exploit living trees as well as dead snags that are available (Smith 2007). This is in line with our results. We found that the proportion of cavities excavated in snags by this species increased two-fold between the pre-outbreak and outbreak periods, despite finding no preference for this type of trees.

For the middle spotted woodpecker, Pasinelli (2000) did not find a significant relationship between the amount of dead wood and the territory size. Lovaty (2002) found high densities of this species in lowland mature oak forest, more than 1.5 territory $10 \mathrm{ha}^{-1}$ on average, despite all standing dead wood being removed from the study area. Moreover, 
Table 7 Model coefficients and odds ratios of the environmental variables included in the best ranked model explaining niche differentiation between great spotted and middle spotted woodpeckers in response to dead wood supply

\begin{tabular}{|c|c|c|c|c|c|c|}
\hline Variable & Estimate & SE & $\begin{array}{l}2.5 \% \\
\mathrm{CL}\end{array}$ & $\begin{array}{l}97.5 \% \\
\text { CL }\end{array}$ & $\begin{array}{l}\text { Odds } \\
\text { ratio }\end{array}$ & $\begin{array}{l}\text { Odds ratio } \\
\text { CI }\end{array}$ \\
\hline Tree species-other & 0.816 & 0.447 & -0.058 & 1.706 & 2.26 & $0.94-5.01$ \\
\hline Tree species_ash & 0.968 & 0.413 & 1.163 & 1.791 & 2.63 & $1.18-5.99$ \\
\hline Dbh & 0.004 & 0.007 & -0.009 & 0.018 & 1.00 & $0.99-1.02$ \\
\hline Tree condition-dead & 1.177 & 0.483 & 0.259 & 2.171 & 3.25 & $1.30-8.76$ \\
\hline Cavity height & -0.029 & 0.030 & -0.089 & 0.029 & 0.97 & $0.92-1.03$ \\
\hline Part of tree-limb/branch & 1.005 & 0.386 & 0.258 & 1.777 & 2.73 & $1.29-5.91$ \\
\hline Wounds-present & 0.519 & 0.418 & -0.279 & 1.372 & 1.68 & $0.76-3.94$ \\
\hline Conks of fungi-present & 0.420 & 0.283 & -0.132 & 0.980 & 1.52 & $0.88-2.67$ \\
\hline Distance to forest edge-closed forest & -0.781 & 0.302 & -1.383 & -0.196 & 0.46 & $0.25-0.82$ \\
\hline $\begin{array}{l}\text { Study period-outbreak } \times \text { tree species- } \\
\text { oak }\end{array}$ & 0.864 & 1.019 & -1.170 & 2.854 & 2.37 & $0.31-17.36$ \\
\hline $\begin{array}{l}\text { Study period-outbreak } \times \text { tree species- } \\
\text { other }\end{array}$ & -0.539 & 1.015 & -2.591 & 1.416 & 0.58 & $0.07-4.12$ \\
\hline $\begin{array}{l}\text { Study period-outbreak } \times \text { tree species- } \\
\text { ash }\end{array}$ & 0.739 & 1.171 & -1.580 & 3.032 & 2.09 & $0.21-20.7$ \\
\hline Study period-outbreak $\times$ Dbh & -0.008 & 0.010 & -0.028 & 0.013 & 0.99 & $0.97-1.01$ \\
\hline $\begin{array}{l}\text { Study period-outbreak } \times \text { tree condition- } \\
\text { dead }\end{array}$ & 0.193 & 0.619 & -1.046 & 1.395 & 1.21 & $0.35-4.04$ \\
\hline Study period-outbreak $\times$ cavity height & 0.043 & 0.045 & -0.045 & 0.131 & 1.04 & $0.96-1.14$ \\
\hline $\begin{array}{l}\text { Study period-outbreak } \times \text { part of tree- } \\
\text { limb/branch }\end{array}$ & -0.222 & 0.610 & -1.426 & 0.973 & 0.80 & $0.24-2.65$ \\
\hline $\begin{array}{l}\text { Study period-outbreak } \times \text { wounds- } \\
\text { present }\end{array}$ & -0.882 & 0.770 & -2.363 & 0.701 & 0.41 & $0.09-2.01$ \\
\hline $\begin{array}{l}\text { Study period-outbreak } \times \text { conks of fungi- } \\
\text { present }\end{array}$ & -0.429 & 0.436 & -1.287 & 0.424 & 0.65 & $0.28-1.53$ \\
\hline $\begin{array}{l}\text { Study period-outbreak } \times \text { distance to } \\
\text { forest edge - closed forest }\end{array}$ & -0.006 & 0.456 & -0.906 & 0.885 & 0.99 & $0.40-2.42$ \\
\hline
\end{tabular}

See Table 6 for the full list of models tested

Stachura-Skierczyńska and Kosiński (2016) did not find a positive relationship between the density of snags and the occurrence and abundance of the middle spotted woodpecker in large-scale studies. Both great spotted and middle spotted woodpeckers show no preferences for foraging on dead trees (Pasinelli and Hegelbach 1997; Robles et al. 2007; Smith 2007), except for in old, near-natural beech forests, where dead wood plays an essential role as a foraging substrate for both species (Hertel 2003). The preferences for dead trees have also been reported during autumn-winter when arthropod availability decreases (Pettersson 1983; Domínguez et al. 2016). Taken together, these studies suggest that the amount of standing dead wood does not affect the abundance of great spotted and middle spotted woodpeckers, irrespective of the spatial scale. On a habitat and landscape scale, middle spotted woodpecker abundance (and density) increases along with the growing number of large living trees and the share of old growth stands (Kosiński and Winiecki 2005; Stachura-Skierczyńska and Kosiński 2016). The most likely mechanism that permits 
this woodpecker species to increase in density is the reduction of its home range size owing to high levels of availability of large rough-barked trees, mainly oaks, related to potential food abundance (Pasinelli 2000). Earlier generalizations suggest that densities of the great spotted woodpecker increase with increasing proportions of old broad-leaved trees, and with increasing amounts of dead wood (Michalek and Miettinen 2003). However, to our knowledge, there are no quantitative models describing relationships between densities and habitat parameters for this species. In our study area, both woodpecker species reached very high densities in both pre-outbreak and outbreak periods compared to other forest stands (Michalek and Miettinen 2003; Pasinelli 2003; Kosiński and Winiecki 2005; Wesołowski et al. 2015). This suggests that the availability of suitable nest sites does not limit the abundance of either woodpecker species in mature riverine forests. Moreover, previous studies did not find unequivocal evidence of the influence of food supply on the abundance of either species. However, changes in the abundance of middle spotted woodpecker have been positively correlated with winter temperatures (Wesołowski and Tomiałojć 1997). Our results are in line with earlier suggestions that the response of cavity nesters to snag density in hardwood stands seems to be weaker than in coniferous forests (Bunnell 2013). The lack of a positive effect of experimentally increased hardwood snag density, from 15 to 33 snags $10 \mathrm{ha}^{-1}$, on the abundance of cavity nesters, including four woodpecker species, has been found in a mixed mesophytic forest in North America (McPeek et al. 1987). On the other hand, it has been found that snag creation in managed pine forests, from 3 to 40 snags ha ${ }^{-1}$ on control and treatment plots respectively, led to an almost 6-fold increase in red-headed woodpecker Melanerpes erythrocephalus populations than on control plots (Kilgo and Vukovich 2014).

Although there were no positive numerical responses from great spotted and middle spotted woodpeckers on the supply of standing dead trees, our data show that standing dead trees were more likely to be used for cavity excavation in the outbreak than pre-outbreak period. Earlier research indicates that woodpeckers appear to select nest sites in dead, soft or decayed parts of trees whose heartwood has been infected by fungi (Jackson and Jackson 2004; Zahner et al. 2012). The preference for dead trees with soft interiors is probably adaptive for woodpeckers, by offering savings in the time and energy required for cavity excavation (Wiebe et al. 2007; Zahner et al. 2012). Presumably, all woodpecker species can identify variations in wood hardness, i.e. they can distinguish between harder sapwood and softer heartwood, both between trees and within the stems (Matsuoka 2008, 2010; Lorenz et al. 2015). Moreover, recent study shows that wood hardness is the most important predictor of nest-site selection at the nest tree and territory scale for six North American woodpecker species inhabiting coniferous forests (Lorenz et al. 2015). Earlier data show that the majority of the nest-holes of great spotted and middle spotted woodpeckers are excavated in limb-holes, open wounds/scars, close to the fruiting body of tree fungus, and in the base of dead or broken limbs (Kosiński et al. 2006; Kosiński and Kempa 2007; Pasinelli 2007; Ćiković et al. 2014). These structures are the primary means by which the fungus gets inside trees causing heart rot, i.e. decay of wood at the center of the trunk and branches. However, trees with characteristics suited for cavity excavation seem to be scarce, even in old growth deciduous forests (Kosiński and Winiecki 2004; Pasinelli 2007; Stachura-Skierczyńska and Kosiński 2016) and coniferous forests (Lorenz et al. 2015). If such structures are rare, then the woodpeckers could benefit from an increasing number of snags, among which at least some should have soft spots suitable for cavity excavation. We did not measure tree hardness; however, since wood hardness decreases from live trees to dead trees (Schepps et al. 1999), we can suppose that dead trees in our study area are more suitable for cavity excavation, and should be preferred over living trees 
(Kosiński and Winiecki 2004). However, the ability of woodpeckers to excavate in trees of different hardness is related to species' morphological adaptations to drilling. The neck muscles of the middle spotted woodpecker are less suitable for drilling and drumming, but are more capable of precise lateral probing movements compared with the great spotted woodpecker (Jenni 1981). Thus, an increase in dead tree density may confer a greater benefit to middle spotted woodpeckers than to great spotted woodpeckers. This supposition is confirmed by our data. The proportion of cavities excavated in snags increased from 18 to $40 \%$ for the middle spotted woodpecker, reaching the value found in primeval forest (Hebda et al. 2016), and from 5 to $13 \%$ for the great spotted woodpecker. Lorenz et al. (2015) suggest that ease of excavation, i.e. preference for sites with soft heartwood, is a major factor driving nest-site selection by woodpeckers in the coniferous forests of northwestern USA. They did not find differences in internal wood hardness of nesting trees; however, they found differences in external (sill) wood hardness (see also Matsuoka 2008). It is likely that the soft external wood of snags is more appropriate for cavity excavation for the middle spotted woodpecker than wounded, decayed or dead places in living trees. This supposition can also be confirmed by the fact that the model including the condition of the tree fragment instead of tree condition received little support. In addition, we found that dead trees were preferred by the species in both pre-outbreak and outbreak periods. Moreover, the presence of wounds and conks of fungi does not significantly affect the nest-site use of the middle spotted woodpecker between study periods. External indicators of wood decay, i.e. presence of the fruiting bodies of polypores, can be fairly unreliable indicators of nest-site availability (Gunn and Hagan 2000; Jusino et al. 2014; Lorenz et al. 2015; but see Pasinelli 2007).

In the outbreak period, tree species other than oak and ash were less likely to be used by middle spotted woodpeckers, and more likely to be used by great spotted woodpeckers compared with the pre-outbreak period. For middle spotted woodpeckers, this was affected by the shift of nest sites into dead trees more suitable for cavity excavation. Among trees other than oaks and ashes, only one tree was classified as dead. Nest niche shifts of great spotted woodpeckers toward tree species other than oak and ash are difficult to explain. Among 21 trees used by this woodpecker species only two were dead. However, most of the cavities (67\%) were excavated in living softwood trees, e.g. birch Betula sp., poplar Populus sp., willow Salix sp., and lime Tilia sp. Since great spotted woodpeckers are able to detect variation in wood hardness among trees (Matsuoka 2010), it is likely that these tree species, if available, play an important role in nest site selection (Wesołowski and Tomiałojć 1986; Stenberg 1996; Smith 2007).

Our data show that great spotted woodpeckers were more likely to excavate cavities in wounds in the outbreak than pre-outbreak period. This could be caused by the increasing number of wounds between study periods. Earlier studies have indicated that time is required for the creation of wounds/cracks and holes, and the development of decay processes in living trees (Ranius et al. 2009; Regnery et al. 2013). The sensitivity of trees to injury seems to increase with the age of the tree, due to the higher probability of microhabitat-creating events caused by any number of mechanical factors (Vuidot et al. 2011). The increasing number of fallen dead trees and limbs observed recently probably plays an important role in the creation of wounds. Injuries created in places on a branch that has been broken off are frequently used for cavity excavation by great spotted woodpeckers (Kosiński et al. 2006; Kosiński and Kempa 2007; Pasinelli 2007; Ćiković et al. 2014).

Our study based on long-term data provides information about patterns of niche partitioning between the great spotted and middle spotted woodpeckers in mature riverine 
forests. We found that the middle spotted woodpecker was more likely to nest in ashes, dead trees, limbs/branches, and less likely to do so in closed forests compared to the great spotted woodpecker. These results expand our earlier knowledge based on univariate analyses (Kosiński and Winiecki 2004; Kosiński et al. 2006). We did not find any significant effects of interaction between nest-site characteristics and the study period which express differences in dead wood availability. Therefore, we suggest that strong increases in standing dead trees did not modify the general pattern of niche partitioning between the great spotted and middle spotted woodpeckers. In contrast to the pre-outbreak period, the frequency of cavities excavated by middle spotted woodpeckers in closed forests increased significantly. This was probably affected by small-scale gap disturbances caused by the death of individual or multiple trees with subsequent falls.

In contrast to our study, Pasinelli (2007) revealed that cavities created by the middle spotted woodpecker were more often freshly excavated, situated close to sporophores, and in dead trees rather than cavities, as is the case for the great spotted woodpecker. However, this study was based on a slightly different set of nest-site attributes, i.e. tree species other than oaks were excluded due to their scarcity, but the position of substrates containing the cavity, and cavity age were included in the analysis. Moreover, Pasinelli (2007) did not include nest location in relation to the forest edge. We did not use cavity age, or the position of the substrate with the cavity in our analysis, since it was not possible to assess this reliably, especially for cavities placed in upper parts of tree crowns. For example, even if cavities seemed to be newly excavated there were no fresh excavation chips on the ground, probably as an effect of dispersion by wind. Moreover, some individuals may begin a cavity that will be completed in following years (Matsuoka 2010; Zahner et al. 2012). Since we did not observe reuse of the same cavities as nest sites in subsequent years by middle spotted woodpeckers, in contrast to a few cases with great spotted woodpeckers (Z. Kosiński unpubl. data; see also Hebda et al. 2016), we can suggest that this species excavates new cavities more frequently than the latter species. This tendency can be enhanced by reuse of the middle spotted woodpecker cavities by the great spotted woodpecker, and nest usurpation by common starlings Sturnus vulgaris (Mazgajski 2003; Kosiński and Ksit 2006; Smith 2006). Thus, the mechanism forcing middle spotted woodpeckers to excavate new holes may be motivated by interspecific competition. Moreover, it has also been found that the lifespan of cavities excavated by woodpeckers in dead trees or dead part of trees is much shorter than in trees with living sapwood (Wesołowski 2011); cavities excavated by middle spotted woodpeckers persisted for a shorter time than those of great spotted woodpeckers, even if excavated in the same type of substrate. All of these results suggest that the middle spotted woodpecker preference for new cavities might be a by-product of interspecific competition, and the shorter lifespan of their cavities.

In our study area, the presence of conks of tree fungi near the cavity did not affect niche differentiation of great spotted and middle spotted woodpeckers. As stated earlier, the presence of conks can be an unreliable indicator of tree hardness (Jusino et al. 2014; Lorenz et al. 2015). Fungi that enter the tree center through wound sites are less destructive for the wood body than heart rot fungi that enter the tree center through old broken limbs which are most frequently seen in standing dead trees (Butin 1983; Zahner et al. 2012). Moreover, primary excavators probably do not select specifically for rot or sporophores, but rather they select trees with considerable wood hardness variation, and soft interiors (Matsuoka 2010; Lorenz et al. 2015).

Standing dead trees have been recognized as an optimal habitat for primary cavity excavators, particularly woodpeckers (Winkler and Christie 2002; Cockle et al. 2011). Our 
findings show that although an increase in the standing dead wood availability does not affect woodpecker population growth in mature riverine forests, it seems to provide habitats that are more favorable, especially for weak excavators, i.e. the middle spotted woodpecker. Snags and cavities are only suitable for nesting for a few years after their creation (Smith 2007; Wesołowski 2011). Therefore, responsible forest management should consider the necessity to leave standing dead wood, dying trees, and trees with low commercial value, and dead wood dynamics, e.g. the rate between the creation and removal/collapse of snags (Smith 2007). Earlier data suggest that it is possible to simultaneously preserve suitable habitat conditions for middle spotted woodpecker populations and maintain the commercial exploitation of a forest with a high economic return when dead wood availability is relatively low, i.e. 5 dead trees ha ${ }^{-1}$ (Stachura-Skierczyńska and Kosiński 2016; see also Lõhmus et al. 2010). Although large-scale dieback of common ashes may have a negative impact on forest ecosystems throughout temperate Europe (Pautasso et al. 2013), our data suggest that this process may locally provide habitats more favorable for middle spotted woodpecker, e.g. in riverine forests where the common ash occurs as an important admixed tree species. However, the decreasing number of ashes and large oaks, and the lack of natural regeneration of the latter species, may negatively affect the middle spotted woodpecker in the future.

\section{Conclusions}

The abundance of great spotted and middle spotted woodpeckers did not increase between 2000 and 2015. This result suggests that the abundances of both species are not affected by an increase in the density of standing dead trees. It is likely that living trees with characteristics suited for cavity excavation preferred by woodpeckers exist in managed mature riverine forests well above the given critical threshold and, therefore, do not limit woodpecker abundance. However, our study demonstrates that differences in standing dead tree availability affect intraspecific nest-site use. The most important factor is that both species, i.e. the generalist forest dweller, the great spotted woodpecker, and the specialist forest dweller, the middle spotted woodpecker, were significantly more likely to use snags in outbreak periods than in pre-outbreak periods. This increase was most visible for the middle spotted woodpecker, i.e. the species with weaker excavating abilities, which clearly prefers nesting in dead trees. An increase in the number of dead trees used by the great spotted woodpeckers should be treated as a random process, as this species did not select snags more frequently according to their availability. This type of substrate probably reduces the energy expenditure of woodpeckers and may be adaptive by offering time and energy savings. However, no study into the fitness consequences of preferred dead trees has yet been conducted and it needs to be determined whether excavating in dead and soft wood is helpful for woodpeckers, e.g. in terms of laying dates and clutch size. It is likely that excavation decisions among the great spotted woodpecker involve the selection of trees with a harder sapwood and a softer heartwood to optimize the energy expenditure in the cavity excavation and the need for nest security.

Acknowledgements We would like to thank Paweł Ksit, Konrad Leniowski and Ewa Węgrzyn for their assistance in the collection of data. We wish to express our gratitude to the Head of Jarocin Forest District and his co-workers for their help during our research. The study was performed with the consent of the Regional Directorate for Environmental Protection in Poznań, and was partly funded by the Polish Science Research Committee (Grant No. 3 P04F 00122). 
Open Access This article is distributed under the terms of the Creative Commons Attribution 4.0 International License (http://creativecommons.org/licenses/by/4.0/), which permits unrestricted use, distribution, and reproduction in any medium, provided you give appropriate credit to the original author(s) and the source, provide a link to the Creative Commons license, and indicate if changes were made.

\section{References}

Angelstam P, Mikusiński G (1994) Woodpecker assemblages in natural and managed boreal and hemiboreal forest-a review. Ann Zool Fenn 31:157-172

Bachmann S, Pasinelli G (2002) Raumnutzung syntop vorkommender Buntspechte Dendrocopos major und Mittelspechte D. medius und Bemerkungen zur Konkurrenzsituation. Ornithol Beob 99:33-48

Barrientos R (2010) Retention of native vegetation within the plantation matrix improves its conservation value for a generalist woodpecker. For Ecol Manag 260:595-602

Bartoń K (2009) MuMIn: multi-model inference. In R package version 0.12.0. http://r-forge.r-project.org/ projects/mumin/

Bates D, Maechler M, Bolker B, Walker S (2014) lme4: Linear mixed-effects models using Eigen and S4. R package version 1.1-7. http://lme4.r-forge.r-project.org/

Bunnell FL (2013) Sustaining cavity-using species: patterns of cavity use and implications to forest management. ISRN For. doi:10.1155/2013/457698

Burnham KP, Anderson DR (2002) Model selection and multimodel inference: a practical informationtheoretic approach, 2nd edn. Springer, New York

Butin H (1983) Krankheiten der Wald- und Parkbäume. Leitfaden zum Bestimmen der Baumkrankheiten. George Thieme Verlag, Stuttgart

Bütler R, Angelstam P, Schlaepfer R (2004) Quantitative snag targets for the three-toed woodpecker Picoides tridactylus. Ecol Bull 51:219-232

Ćiković D, Barišić S, Tutiš V, Kralj J (2014) Nest site and nest-hole characteristics used by Great Spotted Woodpecker Dendrocopos major L. in Croatia. Pol J Ecol 62:349-360

Cockle KL, Martin K, Wesołowski T (2011) Woodpeckers, decay, and the future of cavity-nesting vertebrate communities worldwide. Front Ecol Environ 9:377-382

Czeszczewik D, Walankiewicz W (2006) Logging affects the white-backed woodpecker Dendrocopos leucotos distribution in the Białowieża Forest. Ann Zool Fenn 43:221-227

Czeszczewik D, Walankiewicz W, Mitrus C, Tumiel T (2013) Importance of dead wood resources for woodpeckers in coniferous stands of the Białowieża Forest. Bird Conserv Int 23:414-425

Domínguez J, Carbonell R, Ramírez A (2016) Seasonal changes in habitat selection by a strict forest specialist, the Middle Spotted Woodpecker (Leiopicus medius), at its southwestern boundary: implications for conservation. J Ornithol. doi:10.1007/s10336-016-1415-6

Domokos E, Cristea V (2014) Effects of managed forests structure on woodpeckers (Picidae) in the Niraj valley (Romania): woodpecker populations in managed forests. North-West J Zool 10:110-117

Dormann CF, Elith J, Bacher S, Buchmann C, Carl G, Carré G, Marquéz JRG, Gruber B, Lafourcade B, Leitão PJ, Münkemüller T, McClean C, Osborne PE, Reineking B, Schröder B, Skidmore AK, Zurell D, Lautenbach S (2013) Collinearity: a review of methods to deal with it and a simulation study evaluating their performance. Ecography 36:27-46

Gause GF (1934) The struggle for existence. Williams \& Wilkins, Baltimore

Gunn JS, Hagan JM III (2000) Woodpecker abundance and tree use in uneven-aged managed and unmanaged, forest in northern Maine. For Ecol Manag 126:1-12

Hågvar S, Hågvar G, Mønness E (1990) Nest site selection in Norvegian woodpeckers. Holarct Ecol 13:156-165

Hebda G, Wesołowski T, Rowiński P (2016) Nest sites of middle spotted woodpeckers Leiopicus medius in a primeval forest. Ardea 104:119-128

Hertel F (2003) Habitatnutzung und Nahrungserwerb von Buntspecht Picoides major, Mittelspecht Picoides medius und Kleiber Sitta europaea in bewirtschafteten und unbewirtschafteten Buchenwäldern des nordostdeutschen Tieflandes. Vogelwelt 124:111-132

Hutto RL, Gallo SM (2006) The effects of postfire salvage logging on cavity nesting birds. Condor 108:817-831

Jackson AJ, Jackson BJ (2004) Ecological relationships between fungi and woodpecker cavity sites. Condor 106:37-49

Jenni L (1981) Das Skelettmuskelsystem des Halses von Buntspecht und Mittelspecht Dendrocopos major und medius. J Ornithol 122:57-61 
Johnson MD (2007) Measuring habitat quality: a review. Condor 109:489-504

Jusino MA, Lindner DL, Cianchetti JK, Grisé T, Brazee NJ, Walters JR (2014) A minimally invasive method for sampling nest and roost cavities for fungi: a novel approach to identify the fungi associated with cavity-nesting birds. Acta Ornithol 49:233-242

Kamiński B, Miler AT, Okoński B, Grajewski S, Schwartz K (2011) Floodplain forest technical and monitoring solutions for protection of the Uroczysko Warta floodplain forest. Pol J Environ Stud 20:1193-1201

Kilgo J, Vukovich M (2014) Can snag creation benefit a primary cavity nester: response to an experimental pulse in snag abundance. Biol Conserv 171:21-28

Kosiński Z (2006) Factors affecting the occurrence of middle spotted and great spotted woodpeckers in deciduous forests—a case study from Poland. Ann Zool Fenn 43:198-210

Kosiński Z, Kempa M (2007) Density, distribution and nest-sites of woodpeckers Picidae in a managed forest of Western Poland. Pol J Ecol 55:519-533

Kosiński Z, Ksit P (2006) Comparative reproductive biology of middle spotted woodpeckers Dendrocopos medius and Great Spotted Woodpeckers D. major in a riverine forest. Bird Study 53:237-246

Kosiński Z, Ksit P (2007) Nest holes of great spotted woodpeckers Dendrocopos major and middle spotted woodpeckers D. medius: do they really differ in size? Acta Ornithol 42:45-52

Kosiński Z, Winiecki A (2003) Estimation of the middle spotted woodpecker Dendrocopos medius numbers-a comparison between the mapping technique combined with audio stimulation and the nest searching method. Not Orn 44:43-55 (in Polish with English summary)

Kosiński Z, Winiecki A (2004) Nest-site selection and niche partitioning among the great spotted woodpecker Dendrocopos major and middle spotted woodpecker Dendrocopos medius in riverine forest of Central Europe. Ornis Fenn 81:145-156

Kosiński Z, Winiecki A (2005) Factors affecting the density of the middle spotted woodpecker Dendrocopos medius: a macrohabitat approach. J Ornithol 146:263-270

Kosiński Z, Kempa M, Hybsz R (2004) Accuracy and efficiency of different techniques for censusing territorial middle spotted woodpeckers Dendrocopos medius. Acta Ornithol 39:29-34

Kosiński Z, Ksit P, Winiecki A (2006) Nest sites of great spotted woodpeckers Dendrocopos major and middle spotted woodpeckers Dendrocopos medius in near-natural and managed riverine forests. Acta Ornithol 41:21-32

Kowalski T, Kraj W, Bednarz B (2016) Fungi on stems and twigs in initial and advanced stages of dieback of European ash (Fraxinus excelsior) in Poland. Eur J For Res 135:565-579

Lõhmus A, Kinks R, Soon M (2010) The importance of dead-wood supply for woodpeckers in Estonia. Balt For $16: 76-86$

Lõhmus A, Nellis R, Pullerits M, Leivitis M (2016) The potential for long-term sustainability in seminatural forestry: a broad perspective based on woodpecker populations. Environ Manag 57:558-571

Lorenz TJ, Vierling KT, Johnson TR, Fischer PC (2015) The role of wood hardness in limiting nest site selection in avian cavity excavators. Ecol Appl 25:1016-1033

Lovaty F (2002) Les densités remarquables du pic mar Dendrocopos medius dans les futaies de chênes âgés de I'allier (France): un effet des altérations anthropiques de la forêt. Alauda 70:311-322

Lučan RK, Hanák V, Horáček I (2009) Long-term re-use of tree roosts by European forest bats. For Ecol Manag 258:1301-1306

Matsuoka S (2008) Wood hardness in nest trees of the great spotted woodpecker Dendrocopos major. Ornithol Sci 7:59-66

Matsuoka S (2010) Great spotted woodpeckers Dendrocopos major detect variation in wood hardness before excavating nest holes. Ornithol Sci 9:67-74

Matuszkiewicz JM (2001) Forest communities in Poland. Wydawnictwo Naukowe PWN, Warszawa

Mazgajski TD (2002) Nesting phenology and breeding success in great spotted woodpecker Picoides major near Warsaw (Central Poland). Acta Ornithol 37:1-5

Mazgajski TD (2003) Nesting interaction between woodpeckers and starlings-delayed commensalisms, competition for nest sites or cavity kleptoparasitism? In: Pechacek P \& D'Oleire-Oltmanns W (eds.), Proceedings International Woodpecker Symposium, pp 133-138. Forschungsbericht 48, Nationalparkverwaltung, Berschtesgaden

McPeek GA, McComb WC, Moriarty JJ, Jacoby GE (1987) Bark-foraging bird abundance unaffected by increased snag availability in a mixed mesophytic forest. Wilson Bull 99:253-257

Michalek KG, Miettinen J (2003) Dendrocopos major great spotted woodpecker. BWP Update, vol 5(2). Oxford University Press, Oxford, pp 101-184

Mikusiński G (2006) Woodpeckers: distribution, conservation, and research in a global perspective. Ann Zool Fenn 43:86-95 
Mikusiński G, Angelstam P (1997) European woodpeckers and anthropogenic habitat change: a review. Vogelwelt 118:277-283

Miler AT (2016) Attempt of estimation of hydrometeorological factors influencing on deadwood quantity on area the Uroczysko Warta floodplain forest. In: Infrastructure and ecology of rural areas. Nr II/2/2016, Polska Akademia Nauk, Oddział w Krakowie, pp 491-500. Komisja Technicznej Infrastruktury Wsi. doi:10.14597/infraeco.2016.2.2.034. (in Polish with English summary)

Newton I (1994) The role of nest sites in limiting the number of hole-nesting birds: a review. Biol Conserv 70:265-276

Pasinelli G (2000) Oaks (Quercus sp.) and only oaks? Relations between habitat structure and home range size of the middle spotted woodpecker (Dendrocopos medius). Biol Conserv 93:227-235

Pasinelli G (2003) Dendrocopos medius middle spotted woodpecker, vol 5. Oxford University Press, Oxford, pp 49-99

Pasinelli G (2007) Nest site selection in middle and great spotted woodpeckers Dendrocopos medius \& D. major: implications for forest management and conservation. Biodivers Conserv 16:1283-1298

Pasinelli G, Hegelbach J (1997) Characteristics of trees preferred by foraging middle spotted woodpecker Dendrocopos medius in northern Switzerland. Ardea 85:203-209

Pasinelli G, Hegelbach J, Reyer H-U (2001) Spacing behavior of the middle spotted woodpecker in central Europe. J Wildl Manag 65:432-441

Pautasso M, Aas G, Queloz V, Holdenrieder O (2013) European ash (Fraxinus excelsior) dieback-a conservation biology challenge. Biol Conserv 158:37-49

Pettersson B (1983) Foraging behaviour of the middle spotted woodpecker Dendropocos medius in Sweden. Holarct Ecol 6:263-269

Przybył K (2002) Fungi associated with necrotic apical parts of Fraxinus excelsior shoots. For Pathol 32:387-394

R Core Team (2016) R: a language and environment for statistical computing. R Foundation for Statistical Computing, Vienna, Austria. http://www.R-project.org/

Ranius T, Niklasson M, Berg N (2009) Development of tree hollows in pedunculate oak (Quercus robur). For Ecol Manag 257:303-310

Regnery B, Paillet Y, Couvet D, Kerbiriou C (2013) Which factors influence the occurrence and density of tree microhabitats in Mediterranean oak forests? For Ecol Manag 295:118-125

Rita H, Komonen A (2008) Odds ratio: an ecologically sound tool to compare proportions. Ann Zool Fenn 45:66-72

Roberge JM, Angelstam P, Villard MA (2008) Specialised woodpeckers and naturalness in hemiboreal forests-deriving quantitative targets for conservation planning. Biol Conserv 141:997-1012

Robles H, Ciudad C (2012) Influence of habitat quality, population size, patch size, and connectivity on patch-occupancy dynamics of the middle spotted woodpecker. Conserv Biol 26:284-293

Robles H, Ciudad C, Vera R, Olea PP, Matthysen E (2007) Sylvopastoral management and conservation of the middle spotted woodpecker at the south-western edge of its distribution range. For Ecol Manag 242:343-352

Schepps J, Lohr S, Martin TE (1999) Does tree hardness influence nest-tree selection by primary cavity nesters? Auk 116:658-665

Schoener TW (1974) Resource partitioning in ecological communities. Science 185:27-39

Schwartz K (2008) Ochrona lasów łęgowych i starorzeczy w Nadleśnictwie Jarocin. (Protection of riparian forests and old river beds in Jarocin Forest Inspectorate). Studia i Materiały Centrum Edukacji Przyrodniczo-Leśnej R. 10, Z. 2 (18):99-107 (in Polish with English summary)

Sedgewick JA, Knopf FL (1986) Cavity-nesting birds and the cavity-tree resource in plains cottonwood bottomlands. J Wildl Manag 50:247-252

Short LL (1979) Burdens of the picid hole-excavating habit. Wilson Bull 91:16-28

Smith KW (2005) Has the reduction in nest-site competition from starlings Sturnus vulgaris been a factor in the recent increase of Great Spotted Woodpecker Dendrocopos major numbers in Britain? Bird Study 52:307-313

Smith KW (2006) The implications of nest site competition from starlings Sturnus vulgaris and the effect of spring temperatures on the timing and breeding performance of great spotted woodpeckers Dendrocopos major in southern England. Ann Zool Fenn 43:177-185

Smith KW (2007) The utilization of dead wood resources by woodpeckers in Britain. Ibis 149:183-192

Spiering DJ, Knight RL (2005) Snag density and use by cavity-nesting birds in managed stands of the Black Hills National Forest. For Ecol Manag 214:40-52

Spühler L, Krüsi BO, Pasinelli G (2014) Do Oaks Quercus spp., dead wood and fruiting Common Ivy Hedera helix affect habitat selection of the middle spotted woodpecker Dendrocopos medius? Bird Study 62:115-119 
Stachura-Skierczyńska K, Kosiński Z (2016) Do factors describing forest naturalness predict the occurrence and abundance of middle spotted woodpecker in different forest landscapes? Ecol Indic 60:832-844

Stenberg I (1996) Nest site selection in six woodpecker species. Fauna norv. Ser. C. Cinclus 19:21-38

Thomas FM, Blank R, Hartmann G (2002) Abiotic and biotic factors and their interactions as causes of oak decline in Central Europe. For Pathol 32:277-307

Tomiałojć L (1980) The combined version of the mapping method. In: Oelke H (ed) Bird census work and nature conservation. Göttingen, pp 92-106

Van Horne B (1983) Density as a misleading indicator of habitat quality. J Wildl Manag 47:893-901

Vierling KT, Gentry DJ, Haines AM (2009) Nest niche partitioning of Lewis's and Red-headed woodpeckers in burned pine forests. Wilson J Ornithol 121:89-96

Vuidot A, Paillet Y, Archaux F, Gosselin F (2011) Influence of tree characteristics and forest management on tree microhabitats. Biol Conserv 144:441-450

Walankiewicz W, Czeszczewik D, Mitrus C, Bida E (2002) Snag importance for woodpeckers in deciduous stands of the Białowieża Forest. Not Orn 43:61-71 (in Polish with English summary)

Wargo PM (1996) Consequences of environmental stress on oak: predisposition to pathogens. Ann Sci For 53:359-368

Weggler M, Bühlmann J, Ayé R, Müller M, Müller W, Schwarzenbach Y, Pasinelli G (2013) Starke Bestandszunahme des Mittelspechts Dendrocopos medius im Kanton Zürich und Konsequenzen für Schutzempfehlungen. Ornithol Beob 110:93-112

Wesołowski T (2007) Lessons from long-term hole-nester studies in a primeval temperate forest. J Ornithol 148:395-405

Wesołowski T (2011) "Lifespan" of woodpecker-made holes in a primeval temperate forests: a thirty year study. For Ecol Manag 262:1846-1852

Wesołowski T, Tomiałojć L (1986) The breeding ecology of woodpeckers in a temperate primaeval forestpreliminary data. Acta Ornithol 45:209-232

Wesołowski T, Tomiałojć L (1997) Breeding bird dynamics in a primaeval temperate forest: long-term trends in Białowieża National Park (Poland). Ecography 20:432-453

Wesołowski T, Czeszczewik D, Hebda G, Maziarz M, Mitrus C, Rowiński P (2015) 40 years of breeding bird community dynamics in a primeval temperate forest (Białowieża National Park, Poland). Acta Ornithol 50:95-120

Wiebe KL, Koenig WD, Martin K (2007) Costs and benefits of nest reuse versus excavation in cavitynesting birds. Ann Zool Fenn 44:209-217

Winkler H, Christie DA (2002) Family Picidae (Woodpeckers). In: del Hoyo J, Elliott A, Sargatal J (eds) Handbook of the birds of the world, vol 7. Jacamars to Woodpeckers, Lynx Edicions, Barcelona, pp 296-555

Zahner V, Sikora L, Pasinelli G (2012) Heart rot as a key factor for cavity tree selection in the black woodpecker. For Ecol Manag 271:98-103

Zarnowitz J, Manuwal D (1985) The effects of forest management on cavity nesting birds in northwestern Washington. J Wildl Manag 49:255-263

Zawadzka D, Ciach M, Figarski T, Kajtoch Ł, Rejt Ł (2013) Materiały do wyznaczania i określania stanu zachowania siedlisk ptasich w obszarach specjalnej ochrony ptaków Natura 2000. GDOŚ, Warszawa 